\title{
Hypothyroidism due to TSH receptor mutations
}

INSERM

\section{Source}

INSERM. (1999). Orphanet: an online rare disease and orphan drug data base.

Hypothyroidism due to TSH receptor mutations. ORPHA:90673

Hypothyroidism due to thyroid-stimulating hormone (TSH) receptor mutations is a type

of primary congenital hypothyroidism (see this term), a permanent thyroid hormone deficiency that is present from birth due to thyroid resistance to TSH. 